\title{
PENGGUNAAN POTENSI WILAYAH PERTANIAN SEBAGAI MEDIA PEMBELAJARAN UNTUK MENINGKATKAN HASIL BELAJAR
}

\author{
Misbahul Munir \\ STAI Ma'had Aly Al-Hikam Malang \\ misbah@staima-alhikam.ac.id
}

\begin{abstract}
Observation result in class IV A Madrasah Ibtidaiyah Mafatihul Huda Pujon Malang, it is known that learning is still dominated by teachers using the lecture method. Based on the results of observation, students feel bored, unhappy, and less motivated by the lecture method. From the lack of student motivation, it has an impact on the low student learning outcomes. The purpose of this study is to produce learning media that can improve student learning outcomes through the application of agricultural potential areas using five stages, namely (1) Needs analysis, (2) Study of basic competencies and learning materials, (3) Development of learning programs, (4) Production learning media, (5) Trial / product revision of learning media. The results of this study indicate that the use of the potential of agricultural areas as a learning media for "Makananku Sehat dan Bergizi" subtheme in grade IV is very valid / feasible and student learning outcomes have increased. This is indicated by the test results (1) Media experts included in the assessment category are very valid / feasible with coefficient 0.96 , (2) Learning design experts / teachers included in the assessment category are very valid / feasible with coefficient 0.92 (3) Small group trials included in the assessment category are very valid / feasible with coefficient 0.9 . The learning outcomes of the student on the knowledge aspect increased from $45 \%$ in the pretest to $85 \%$ in the post test, the learning outcomes of the students on the attitudes increased from $65 \%$ in the pretest to $77 \%$ in the post test, and the learning outcomes of student on the skills increased from $64 \%$ in the pretest to $85 \%$ in the post test.
\end{abstract}

Hasil pengamatan di kelas IVA Madrasah Ibtidaiyah Mafatihul Huda Pujon Malang, diketahui pembelajaran masih didominasi oleh guru dengan menggunakan ceramah. Berdasarkan observasi siswa merasa bosan, kurang senang, dan kurang termotivasi oleh metode pembelajaran ceramah. Dari kurangnya motivasi siswa berdampak rendahnya hasil belajar siswa. Tujuan penelitian ini adalah mengahsilkan media pembelajaran yang bisa meningkatkan hasil belajar siswa melalui penerapan potensi wilayah pertanian dengan menggunakan lima tahap. (1) Analisis kebutuhan, (2) Kajian kompetensi dasar dan materi pembelajaran, (3) Pengembangan program pembelajaran, (4) Produksi media pembelajaran, (5) uji coba/revisi produk media pembelajaran. Hasil penelitian ini menunjukkan bahwa penggunaan potensi wilayah pertanian sebagai media pembelajaran subtema makananku sehat dan bergizi kelas IV MI sangat valid/layak dan hasil belajar siswa mengalami peningkatan. Hal ini ditunjukkan oleh hasil uji (1) Ahli media termasuk dalam kategori penilaian sangat valid/layak dengan koevisiensi 0,96. (2) Ahli desain pembelajaran/Guru kriteria sangat valid/layak dengan koevisien 0,92. (3) Uji coba kelompok kecil dengan kategori sangat valid/layak dengan koevisien 0,9. Hasil belajar ranah pengetahuan siswa mengalami peningkatan dari $45 \%$ pada pretest menjadi $85 \%$ pada posttest, hasil belajar ranah sikap siswa telah meningkat dari $65 \%$ pada pretest menjadi $77 \%$ pada posttest, dan hasil belajar ranah keterampilan siswa meningkat dari $64 \%$ pada prestest menjadi $85 \%$ pada posttest.

Vol. 1 No. 2 Oktober 2018

AL - MUDARRIS homepage: http://e-journal.staima-alhikam.ac.id/index.php/almudarris/index 
Keywords: Media of Learning, The Coastel Region, Learning Outcome

\section{A. PENDAHULUAN}

Proses belajar mengajar selama ini masih banyak ditemui problem kurang tepat pada penggunaan strategi pembelajarannya. Metode ceramah masih menjadi dominasi dalam pemilihan strategi pembelajaran yang banyak digunakan oleh guru dalam proses belajar mengajar, padahal subyek dalam proses pembelajaran tingkatan madrasah ibtidaiyah masih bersifat konkrek dalam penalarannya sehingga perlu adanya media pendamping pembelajaran. Seharusnya materi yang diajarkan harus bersifat konkret melalui media pembelajaran, dengan mempergunakan indera yang dialami oleh siswa secara langsung, bukan bersifat konsep teoritis. ${ }^{1}$

Berdasarkan hasil observasi langsung pada pelaksananaan proses belajar mengajar pada kelas IV MI Mafatihul Huda Madiredo Pujon Malang, pembelajaran yang digunakan masih monoton menggunakan metode ceramah. Kondisi yang peniliti amati pada observasi awal masih banyak siswa yang mengobrol sendiri, tidak fokus pada guru yang menyampaikan materi pembelajaran. Fakta lain yang peneliti temui, masih ada siswa yang tidak membawa buku paket tematik. Bisa asumsikan bahwa kurangnya buku penunjang pembelajaran selain buku paket yang ada diperpustakaan. Letak lokasi sekolah yang jauh dari perkotaan, serta kurangnya media untuk mengakses informasi penunjang belajar. Dampat yang diakibatkan oleh proses belajar yang monoton, memberi pengaruh pada hasil belajar siswa. Dari 20 siswa yang ada, masih terdapat 11 siswa yang belum mencapai nilai 70 dari kriteria ketuntasan minimal.

Salah satu hal yang menarik untuk diteliti di Madrasah Ibtidaiyah Mafatihul Huda Madiredo Pujon Malang, adalah letak sekolah yang berada jauh dari perkotaan. Letak sekolah memiliki media alam pegunungan dan hamparan pertanian, diharapkan dapat memberikan motivasi bagi siswa. Disisi lain media lingkungan yang di sekitar madrasah, bisa menjadi alternatif sumber belajar yang menarik dan tidak membosankan. Siswa bisa melakukan pengamatan, bertanya, demontrasi pembuktian, menguji fakta, dan lain lain sesuai dengan kaidah pembelajaran saintifik. ${ }^{2}$

Dalam proses kegiatan belajar mengajar di sekolah tidak sedikit problematika berkenaan dengan karakteristik belajar siswa yang beranekaragam. Ada siswa siswa mudah dalam mencerna pelajaran yang disampaikan oleh guru, tidak sedikit pula siswa yang mengalami kesulitan dalam mencerna pembelajaran. Salah satu solusi yang hendak ditawarkan oleh peneliti terkait media pembelejaran yang mengintergrasikan keterlibatan isi materi dengan lingkungan sekitar sekolah sebagai media pembelajaran, pada ranah kognitif bisa dikatakan dapat memberikan pengaruh secara bertahap dari berfikir yang konkret ke berfikir abstrak. ${ }^{3}$

Lingkungan belajar siswa yang bisa digunakan sebagai media pembelajaran bersifat konkret sedangkan materi pembelajaran bersifat abstrak. Memungkinkan melalui pembelajaran secara langsung dari lingkungannya, siswa memperoleh

\footnotetext{
${ }^{1}$ Penekanan pada keampuan berpikir kreatif siswa, baik melalui penalaran terhadap fenomena yang ditemui secara langsung, mencari pemecahan masalah, serta mampu mengambil keputusan. Tajularipin Sulaiman, dkk, "Implementation of Higher Order Thinking Skills in Teaching of Science : A Case Study in Malaysia" International Research Journal of Education and Sciense (Irjes) vol.1 Issue. 1 2017

${ }^{2}$ Maria Varelas dan Michael Ford, The Scientific Method and Scientific Inquiry: Tensions in Teaching and Learning, (USA: Wiley InterScience, 2009), hlm 31

Mary Forehad, "Bloom'sTaxonomy: Original and Revised", diakses dari http://sciencesite.16mb.com, pada tanggal 20 Agustus 2018 pukul 08.00

Vol. 1 No. 2 Oktober 2018

AL - MUDARRIS homepage: http://e-journal.staima-alhikam.ac.id/index.php/almudarris/index
} 
pengetahuan berdasarkan fakta objektif dan mampu membuat analis dari proses belajarnya. Guru mengarahkan dan memberi dorongan kepada siswa agar mampu melakukan observasi, bertanya, menalar serta mengkomunikasikan apa yang diperoleh siswa dalam belajar. ${ }^{4}$

Berdasarkan wawancara dengan guru masih belum mampu untuk mengembangkan media pembelajaran yang berkaitan dengan potensi wilayah sekolah yang termasuk wilayah pertanian. Penerapan kurikulum 2013 berbeda dengan kurikulum sebelumnya, kurikulum 2013 berisi materi tematik integratif semua mata pelajaran, sehingga menyulitkan guru dalam mengembangkan pembelajaran.

Berdasarkan temuan diatas, peneliti mencoba memberikan alternatif solusi untuk menyelesaikan probelmatika tersebut dengan melakukan pengembangan produk media pembelajaran sesuai dengan lokalitas potensi wilayah pertanian di Madrasah Ibtidaiyah Mafatihul Huda Pujon Malang pada siswa kelas IV subtema Makanku Sehat dan Bergizi.

\section{B. METODE PENELITIAN}

Penelitian dan pengembangan yang digunakan dalam penelitian ini ialah untuk menghasilkan produk media pembelajaran berbasis potensi wilayah pertanian, serta menguji produk bahan ajar hasil pengembangan. ${ }^{5}$ Model yang digunakan ialah dengan melalukan define, design, development and dissemination sesuai dengan alur dari Sivasailam Thiagarajan, dkk. ${ }^{6}$ Diadaptasi menjadi pendefinisian, perancangan, pengembangan, serta penyebaran atau disebut juga model 4-P. ${ }^{7}$ Subjek dalam penelitian ini adalah siswa Madrasah Ibtidaiyah Mafatihul Huda Madiredo Pujon Malang, sebagai sampel 20 siswa.

Pendefinisian terkait dengan penentuan kebutuhan dalam proses belajar mengajar serta menggali beberapa informasi yang berguna untuk pengembangan produk, langkah yang dilakukan antara lain dengan melakukan analisis siswa dan konsep pembelajaran. Langkah ini dilakukan untuk memperoleh gambaran terkait kurikulum dan media yang digunakan di Madrasah Ibtidaiyah Mafatihul Huda Madiredo, mengetahui permasalahan yang dihadapi oleh siswa dan guru hingga mencari solusi yang tepat.

Langkah berikut analisis siswa yang bertujuan untuk memperoleh informasi terkait karakteristik dan masalah-masalah belajar yang dihadapi oleh siswa. Langkah ini bertujuan untuk identifikasi, merinci, dan menyusun materi kelas 4 Madrasah Ibtidaiyah tema subtema Makananku Sehat dan Bergizi pembelajaran 1 sampai dengan 6. Langkah selanjutnya yang dilakukan adalah melakukan identifikasi terkait tujuan pembelajaran.

Langkah pertama dalam perancangan bahan ajar yaitu menyusun materi dan soal yang terdapat dalam buku ajar sesuai dengan indikator serta kompetensi K1 sampai KI 4 dalam subtema Makananku Sehat dan Bergizi. Langkah kedua merancang media pembelajaran berdasarkan muatan isi materi, kompetensi yang dikembangakan sesuai dengan karakteristik siswa.

${ }^{4}$ Kemdikbud, Pendekatan Scientific (Ilmiah) dalam Pembelajaran, (Jakarta: Pusbangprodik, 2013), hlm.3-4. 407.

${ }^{5}$ Sugiyono, Metode Penelitian Kuantitatif, kualitatif dan $R \&$ D, (Bandung: Alfabeta, 2012), hlm.

${ }^{6}$ Sivasailam Thiagarajan, dkk., Instructional Development for Training Teachers of Expectional Children, (Minneapolis : Leadership Training Institute/Special Education University of Minnesota, 1974), hlm. 8. hlm.189

${ }^{7}$ Trianto, Mendesain Model Pembelajaran Inovatif Progresif, (Jakarta: Kencana Prenada, 2010),

Vol. 1 No. 2 Oktober 2018

AL - MUDARRIS homepage: http://e-journal.staima-alhikam.ac.id/index.php/almudarris/index 
Langkah pengembangan meliputi uji validasi produk pengembangan, melalui uji validasi ahli media, ahli desain pembelajaran, uji kelompok kecil untuk memperoleh data kelayakan produk pengembangan. Uji validasi diperoleh melalui soal terbuka dan tertutup berupa angket, soal terbuka digunakan sebagai gambaran masukan dari validator oleh para ahli sebagai masukan bahan revisi. Hasil validasi dipergunakan untuk mendapatkan informasi terkait bahan ajar siap digunakan dilapangan atau masih memerlukan revisi.

Hasil validasi produk bahan ajar yang memenuhi kualifikasi valid dapat diujikan pada kelompok kecil siswa Madrasah Ibtidaiyah Mafatihul Huda Madiredo Pujon kelas IV yang berjumlah 10 siswa untuk mendapatkan respon masukan tanggapan siswa terkait produk media pembelajaran. Pengujian melalui kelas besar dilakukan setelah bahan ajar memenuhi kualifikasi vali/layak dipergunakan untuk mengambil data terkait keefektifan dalam ranah pengetahuan, sikap, dan keterampilan yang setelah menggunakan media pembelajaran berbasis potensi wilayah pertanian. Langkah terakhir adalah penyebaran informasi terkait produk media prmbelajaran yang berupa buku terintegrasi dengan potensi wilayah pertanian melalui publikasi di jurnal Mudarris prodi PGMI STAI Ma'had Aly Al-Hikam Malang.

Data yang diperoleh dalam penelitian ini berupa data kualitatif dan kuantitatif,. Data kualitatif diperoleh dari angket terbuka, wawancara, observasi yang dipergunakan sebagai masukan dalam pengembangan produk pengembangan media pembelajaran. Data kuantitatif didapat melalui angket yang bersifat tertutup terkait uji kevalidan melalui ahli materi, ahli desain pembelajaran, dan uji kelompok kecil. Data kuantitatif lainnya diperoleh dari hasil keefektifan media meningkatan hasil belajar siswa.

\section{DATA DAN SUMBER DATA}

Penyajian hasil data yang diperoleh penelitian ini sebagaimana pada tabel 1 dibawah ini.

Tabel 1. Data, Sumber Data, Intrumen penelitian

\begin{tabular}{llll}
\hline $\begin{array}{l}\text { Data } \\
\text { Ahli Media }\end{array}$ & $\begin{array}{l}\text { Sumber Data } \\
\text { Pakar/Ahli } \\
\text { Guru/Dosen }\end{array}$ & $\begin{array}{l}\text { Aspek } \\
\text { Desain Visual Media }\end{array}$ & $\begin{array}{l}\text { Instrumen } \\
\text { Angket terbuka } \\
\text { kualitatif dan } \\
\text { angket tertutup } \\
\text { kuantitatif }\end{array}$ \\
Uji Kelompok Kecil & Siswa & Penyerapan Materi & \\
& Suru Kelas & Materi Pembebelajaran & \\
\hline Hasil Belajar & Siswa & $\begin{array}{l}\text { Pengetahuan } \\
\text { Sikap } \\
\text { Keterampilan }\end{array}$ & $\begin{array}{l}\text { Uji tes kognitif } \\
\text { Lembar } \\
\text { observasi } \\
\text { afektif }\end{array}$ \\
& & &
\end{tabular}

Pada Tabel 1 sumber data yang diperoleh dalam penelitian ini yaitu melalui uji kelayakan dari para ahli (media, desain pembelajaran, kelompok kecil siswa) melalui angket secara terbuka dan tertutup sebagai bahan masukan uji kelayakan. Sedangkan hasil pembelajaran diperoleh melalui uji tes pengetahuan serta dari lembar observasi sikap dan keterampilan. 
A L - MUDARRIS

Journal of Education

p ISSN: $2620-5831$ | e ISSN:2620-4355

\section{HASIL DAN PEMBAHASAN}

\section{Penilaian Para Ahli dan Uji Kelompok Kecil}

Skor prosentasi kriteria kelayakan media pembelajaran berdasarkan peniliaian para ahli diperoleh sebagaimana Tebel 2 dibawah ini.

\begin{tabular}{lccl}
\hline \multicolumn{1}{c}{ Data } & Interval Koevisien & \multicolumn{1}{c}{ Kriteria } \\
Ahli Media & 0,96 & Sangat Valid/Layak \\
Ahli & Desain & 0,92 & Sangat Valid/Layak \\
Pembelajaran & 0,9 & Sangat Baik/Layak \\
Uji Kelompok Kecil & & \\
\hline
\end{tabular}

Berdasarkan Tabel 2 yang diperoleh melalui uji para ahli kriteria media pembelajaran menunjukkan gambaran kriteria layak dan dapat dipergunakan sebagai media dalam proses belajar mengajar, sebagaimana diperoleh data dari ahli media dengan koevisien 0,96 sangan valid/layak, ahli desain pembelajaran dengan koevisien 0,92 sangat valid/layak, dan uji kelompok kecil siswa 0,9 sangat valid/layak.

Penilaian media pembelajaran sebagai langkah awal untuk mengetahui kelayakan dari media pembelajaran yang kembangkan, apakah media sudah layak untuk digunakan dalam proses pembelajaran atau masih membutuhkan revisi perbaikan. Sebagaimana menurut Thiagarajan, dkk. "expert appraisal is a technique for obtaining suggestions for the improvement of the material." Sedangkan uji coba kelompok kecil data respon, reaksi dan komentar siswa terhadap media pembelajaran menunjukkan penilaian layak. Dari uji para ahli bahan ajar mendapat respon layak, sehingga bisa dilanjutkan untuk tahan uji selanjutnya terkait keefektifan dalam meningkatkan hasil belajar siswa.

\section{Hasil Belajar Siswa}

Hasil belajar meliputi tiga ranah yaitu ranah pengetahuan, sikap, dan keterampilan. ${ }^{9}$ Pada penelitian ini pengukuran hasil belajar siswa ranah pengetahuan diukur melalui kajian seberapa jauh penguasaan materi pembelajaran yang diserap oleh siswa. Ranah sikap untuk mengetahui sikap siswa terhadap materi, terhadap proses pembelajaran, dan sikap kepada guru. Ranah keterampilan berkaitan dengan tingkat keahlian yang dimiliki siswa dalam melaksanakan tugas pembelejaran.

\section{Hasil Belajar Ranah Pengetahuan}

Perolehan data hasil kognitif berdasarkan Pretest dan Posttest. Pretest diperoleh dari proses pembelajaran siswa sebelum menggunakan media hasil pengembangan, Posttest diperoleh dari proses pembelajaran setelah menggunakan media hasil pengembangan. Lebih detailnya dalam tabel 3 dibawah ini.

Tabel 3. Perbandingan Nilai Hasil Belajar Prestest dan Postest

\begin{tabular}{lcccc}
\hline & Nilai rata-rata & $\begin{array}{c}\text { Junlah Siswa } \\
\text { Tidak Tuntas }\end{array}$ & $\begin{array}{c}\text { Jumlah Siswa } \\
\text { Tuntas }\end{array}$ & $\begin{array}{c}\text { Prosentase } \\
\text { Ketuntasan }\end{array}$ \\
Pretest & 69 & 11 & 9 & $45 \%$ \\
Posttest & 77 & 3 & 17 & $85 \%$ \\
\hline
\end{tabular}

Hasil perbandingan nilai Pretest dan Posttest pada ranah kognitif mengalami peningkatan sebesar 40\%. Nilai ketuntasan belajar pada saat Pretest diperoleh sebesar 45\%, sedangkan pada saat Postest diperoleh nilai sebesar $85 \%$. Sedangkan pada nilai

\footnotetext{
${ }^{8}$ Sivasailam Thiagarajan, dkk., Instructional Development for Training Teachers.., hlm.8.

9 Anderson, L. W., dkk., A Taxonomy for Learning, Teaching, and Assessing: A Revision of Bloom's Taxonomy of Educational Objectives, (New York: Longman, 2010), hlm. 28.

Vol. 1 No. 2 Oktober 2018

AL - MUDARRIS homepage: http://e-journal.staima-alhikam.ac.id/index.php/almudarris/index
} 
rata-rata yang diambil pada saat Pretest diperoleh nilai 69 sedangkan untuk Posttest mengalami peningkatan diperoleh nilai 77 , adapun kriteria ketuntasan minimal belajar yang diteteapkan adalah nilai 70 .

Dalam ranah pengetahuan serapan materi terdapat peningkatan yang sangat signifikan, dari total 20 siswa sebelum menggunakan media pembelajaran hasil pengembangan hanya terdapat 9 siswa tuntas belajar, sedangkan sisanya 11 siswa masih belum tuntas. Sedangkan pada setelah menggunakan media pembelajaran hasil pengembangan terdapat peningkatan signifikan, dari 20 siswa hanya 3 siswa belum tuntas belajarnya.

Hasil tersebut menunjukkan bahwa keterkaitan pola belajar siswa dengan media dan lingkungan tempat belajarnya sangat penting. Siswa menyerap informasi pengetahuan tidak dijauhkan dari karakteristik lingkungan sekitarnya. Interaksi aktif siswa dengan lingkungan belajarnya inilah menurut pandangan Tennyson ${ }^{10}$, belajar adalah kegiatan aktif, mandiri, mengarahkan, serta eksplorasi terhadap lingkungan untuk mengkonstruksi pengetahuan.

\section{Hasil Belajar Ranah Sikap}

Perbandingan dari pengukuran hasil observasi terhadap siswa yang dilakukan pada saat siswa sebelum dan sesudah siswa menggunakan media hasil pengembangan sebagaimana pada Tabel. 4 berikut ini.

Tabel 4. Perbandingan Nilai Sikap Siswa Sebelum dan Sesudah Menggunakan Media

\begin{tabular}{|c|c|c|c|c|c|}
\hline \multirow{2}{*}{\multicolumn{2}{|c|}{ SIKAP }} & \multicolumn{2}{|c|}{ Pretest } & \multicolumn{2}{|c|}{ Posttest } \\
\hline & & $\begin{array}{c}\text { Prosentase } \\
\%\end{array}$ & Kriteria & $\begin{array}{c}\text { Prosentase } \\
\%\end{array}$ & Kriteria \\
\hline \multirow[t]{3}{*}{ Proses Belajar } & Aktif & 50 & Kurang & 80 & Baik \\
\hline & Disiplin & 55 & Kurang & 70 & Cukup \\
\hline & Memperhatikan & 65 & Cukup & 80 & Baik \\
\hline Materi & Rasa ingin tahu & 60 & Kurang & 70 & Cukup \\
\hline \multirow{2}{*}{ Pembelajaran } & Kreatif & 60 & Kurang & 80 & Baik \\
\hline & Antusias & 65 & Cukup & 80 & Baik \\
\hline \multirow[t]{3}{*}{ Terhadap Guru } & Sopan Santun & 80 & Baik & 80 & Baik \\
\hline & Hormat & 80 & Baik & 80 & Baik \\
\hline & Tanggungjawab & 70 & Cukup & 80 & Baik \\
\hline \multicolumn{2}{|c|}{ Prosentase Skor Total Ranah Afektif \% } & 65 & Cukup & 77 & Baik \\
\hline
\end{tabular}

Berdasarkan Tabel 4. Terdapat peningkatan total hasil belajar secara kognitif siswa sebesar $12 \%$, adapun nilai total hasil belajar pada Pretest diperoleh $65 \%$ dan Posttest diperoleh total hasil $77 \%$.

Pada ranah sikap mengalami perubahan signifikan dalam hal proses pembelajaran yang meliputi keaktifan, kedisiplinan, dan perhatian siswa selama proses belajar. Selain itu perubahan lainnya terdapat perubahan pada sikap siswa terhadap materi pembelajaran, yakni rasa ingin tahu, kreatif dan antusias terhadap materi yang diperoleh selama proses belajar. Sedangkan pada ranah sikap terhadap guru tidak mengalami

10 Tennyson, R, D. "Historical reflection on learning theories and instructional design", Contemporary Educational Technology, Vol.1, hlm.7.

Vol. 1 No. 2 Oktober 2018

AL - MUDARRIS homepage: http://e-journal.staima-alhikam.ac.id/index.php/almudarris/index 
peningkatan signifikan, namun bukan berarti sikap siswa terhadap guru rendah, melainkan sikap siswa terhadap guru dalam hal sopan santun, hormat, dan tanggung jawab terhadap tugas yang diberikan guru sudah baik.

Hasil pengukuran sikap baik dalam proses belajar, terhadap materi pembelajaran, dan kepada guru sangat penting untuk diukur. Hasil pengukuran sikap berguna untuk mengetahui sejauh mana minat siswa terhadap pembelajaran yang dilakukannya, jika minat siswa rendah bisa berguna untuk menentukan strategi pembelajaran yang tepat. ${ }^{11}$

\section{Hasil Belajar Ranah Keterampilan}

Perbandingan dari tetuntasan keterampilan siswa sebelum dan sesudah menggunakan media pembelejaran sebagaiman pada Tabel 5 dibawah ini.

\section{Tabel 5. Perbandingan Pengukuran Keterampilan Siswa Sebelum dan Sesudah} Menggunakan Media

\begin{tabular}{|c|c|c|c|c|}
\hline \multirow[b]{2}{*}{ Keterampilan } & \multicolumn{2}{|c|}{ Pretest } & \multicolumn{2}{|c|}{ Posttest } \\
\hline & $\begin{array}{c}\text { Prosentase } \\
\%\end{array}$ & Kriteria & $\begin{array}{c}\text { Prosentase } \\
\%\end{array}$ & Kriteria \\
\hline $\begin{array}{l}\text { Melakukan kegiatan mengamati dengan } \\
\text { benar }\end{array}$ & 65 & Cukup & 95 & $\begin{array}{l}\text { Sangat } \\
\text { Baik }\end{array}$ \\
\hline $\begin{array}{l}\text { Menggunakan peralatan dengan benar } \\
\text { Melakukan pengamatan dengan sistematis } \\
\text { dan benar }\end{array}$ & 65 & Cukup & 90 & $\begin{array}{l}\text { Sangat } \\
\text { Baik }\end{array}$ \\
\hline Kerjasama dengan kelompok baik & 60 & Kurang & 95 & $\begin{array}{l}\text { Sangat } \\
\text { Baik }\end{array}$ \\
\hline $\begin{array}{l}\text { Menjaga kebersihan dan kerapiah selama } \\
\text { proses bembelajaran berlangsung }\end{array}$ & 65 & Cukup & 80 & Baik \\
\hline Prosentase Skor Total Ranah Afektif \% & 64 & Cukup & 90 & $\begin{array}{l}\text { SangatB } \\
\text { aik }\end{array}$ \\
\hline
\end{tabular}

Berdasarkan hasil penilaian keterampilan siswa mengalami peningkatan sebesar $26 \%$. Nilai keterampilan diperoleh ketika sebelum menggunakan media pembelajaran $64 \%$, sedangkan nilai keterampilan setelah menggunakan media pembelajaran diperoleh $90 \%$. Sejalan dengan pendapat Sudjana, ${ }^{12}$ pengukuran dalam penilaian keterampilan berguna untuk mengetahu output skill yang diperoleh siswa selama proses pembelajaran, kemampuan motorik yang diterima siswa dalam proses belajar dapat menjadi pengalaman siswa dalam menentukan tindakan pada proses belajar tingkat yang lebih tinggi selanjutnya.

\section{E. KESIMPULAN}

Media pembelajaran dengan menggunakan potensi wilayah pertanian kelas IV subtema makananku sehat dan bergizi di Madrasah Ibtidaiyah Mafatihul Huda Pujon Malang dikembangkan menggunakan lima tahap. (1) Analisis kebutuhan, (2) Kajian

11 Sukanti, "Penilaian Afektif dalam Pembelajaran Akuntansi" Jurnal Pendidikan Akuntansi Indonesia, Vol. IX Tahun 2011, hlm. 77.

${ }^{12}$ Nana Sudjana, Penilaian Hasil Proses Belajar Mengajar, (Bandung: Remaja Rosdakarya, 2009), hlm. 31.

Vol. 1 No. 2 Oktober 2018

AL - MUDARRIS homepage: http://e-journal.staima-alhikam.ac.id/index.php/almudarris/index 
kompetensi dasar dan materi pembelajaran, (3) Pengembangan program pembelajaran, (4) Produksi media pembelajaran, (5) uji coba/revisi produk media pembelajaran.

Hasil penelitian ini menunjukkan bahwa penggunaan potensi wilayah pertanian sebagai media pembelajaran subtema makananku sehat dan bergizi kelas IV MI telah dikembangkan dengan kualifikasi "sangat valid/layak". Hal ini ditunjukkan oleh (1) Ahli media termasuk dalam kategori penilaian "sangat valid/layak" dengan koevisiensi 0,96.

(2) Ahli desain pembelajaran/Guru kriteria "sangat valid/layak" dengan koevisien 0,92.

(3) Uji coba kelompok kecil dengan kategori "sangat valid/layak." Hasil belajar ranah pengetahuan siswa mengalami peningkatan dari $45 \%$ pada pretest menjadi $85 \%$ pada posttest, hasil belajar ranah sikap siswa telah meningkat dari $65 \%$ pada pretest menjadi $77 \%$ pada posttest, dan hasil belajar ranah keterampilan siswa meningkat dari $64 \%$ pada prestest menjadi $85 \%$ pada posttest.

\section{DAFTAR RUJUKAN}

Anderson, L. W., dkk., A Taxonomy for Learning, Teaching, and Assessing: A Revision of Bloom's Taxonomy of Educational Objectives, New York: Longman, 2010.

Kemdikbud, Pendekatan Scientific (Ilmiah) dalam Pembelajaran, Jakarta: Pusbangprodik, 2013.

Mary Forehad, "Bloom'sTaxonomy: Original and Revised", diakses dari http://sciencesite.16mb.com, pada tanggal 20 Agustus 2018 pukul 08.00

Maria Varelas dan Michael Ford, The Scientific Method and Scientific Inquiry: Tensions in Teaching and Learning, USA: Wiley InterScience, 2009.

Nana Sudjana, Penilaian Hasil Proses Belajar Mengajar, Bandung: Remaja Rosdakarya, 2009.

Sivasailam Thiagarajan, dkk., Instructional Development for Training Teachers of Expectional Children, Minneapolis : Leadership Training Institute/Special Education University of Minnesota, 1974.

Sugiyono, Metode Penelitian Kuantitatif, kualitatif dan $R \& D$, Bandung: Alfabeta, 2012.

Sukanti, "Penilaian Afektif dalam Pembelajaran Akuntansi" Jurnal Pendidikan Akuntansi Indonesia, Vol. IX Tahun 2011.

Tajularipin Sulaiman, dkk, "Implementation of Higher Order Thinking Skills in Teaching of Science : A Case Study in Malaysia” International Research Journal of Education and Sciense (Irjes) vol.1 Issue. 12017

Tennyson, R, D. "Historical reflection on learning theories and instructional design", Contemporary Educational Technology, Vol.1, hlm.7.

Trianto, Mendesain Model Pembelajaran Inovatif Progresif, Jakarta: Kencana Prenada, 2010. 